\title{
Urban Sprawl Assessment and Its Effect on Land Use Transformation in Varanasi City using Remote Sensing and GIS
}

\author{
Uzma Ashraf, Abdul Munir
}

\begin{abstract}
This paper seeks to examine the effect of urbanization on changes in land use in the peri-urban areas of Varanasi city in India. The area of study is divided into six different classes of land use: built-up area, agriculture, vegetation, water bodies, sand and other land use. Using the maximum likelihood technique, Landsat 5 TM satellite data were used to identify land use and land cover changes from 1996 to 2017. The findings indicate a substantial increase in the built-up area, associated with reduced water and other land use cover. The urban sprawl is observed in almost all directions from the city boundaries, and along highways. Shannon's entropy analysis reveals dispersed distribution of built-up area. The approach based on GIS and remote sensing data, together with statistical analysis, has proved instrumental in the analysis of urban expansion. It also helps to identify priority areas that require adequate planning for sustainable development.
\end{abstract}

Keywords : GIS, land use, remote sensing, urban sprawl.

\section{INTRODUCTION}

Urbanization is occurring rapidly across the globe. This has led to complex and uncoordinated urban, and peri-urban physical growth, which has impacted land use as well as land cover. This rapid growth has a substantial socioeconomic and environmental impact. It is altering the terrestrial environment with huge magnitude at an unprecedented rate. Rising population and unplanned development of cities forces change in land use, which negatively affects water bodies, and peri-urban agricultural land [1]. The situation requires monitoring of urban and peri-urban landscape, with a focus on sustainable development, for proper land use planning.

The extent of urbanization, or sprawl, is characterized by low-density, haphazard development spreading radially from the urban centre, or linearly along highways. Researchers have been trying to analyze the effect of sprawl on land use / land use in recent years [2]-[5]. It has been proposed that the sprawl contributes to a shift in land use, with a rise in the proportion of built-up area [6]. This adversely impacts peri-urban environment. Increased air pollution, water

Revised Manuscript Received on December 30, 2019.

* Correspondence Author

Uzma Ashraf*, Department of Geography, Aligarh Muslim University, Aligarh, India. Email: uzmashraf1@gmail.com

Abdul Munir, Department of Geography, Aligarh Muslim University, Aligarh, India. Email: abdulmunir.amu@gmail.com

(C) The Authors. Published by Blue Eyes Intelligence Engineering and Sciences Publication (BEIESP). This is an open access article under the CC BY-NC-ND license (http://creativecommons.org/licenses/by-nc-nd/4.0/) pollution, shortage of agricultural land are some of the major problem associated with sprawl.

The development of peri-urban areas along transportation routes promotes socio-economic activities like establishment of motels, colleges, malls, and small industries. Further, it facilitates business and industrial activities. These opportunities serve as a pull factor for migrants. The migration takes place from rural to urban area, mainly for job and schooling. The United Nations World Urbanization Prospects 2018 highlights that China and India are the home of $30 \%$ of the total urban population of the world [7]. 34.5 percent of the Indian population is estimated to live in urban areas. India, China, and Nigeria are expected to contribute to the world's urban population growth of 35 percent between 2018 to 2050. India will contribute the most with 41.6 crores (416 million) urban dwellers. It is expected that Indian urban population will reach $50 \%$ by 2046 . At the same time, the rural population of the country will decline by 11.1 crores (111 million). This implies that a study on the dynamics of urban sprawl in the Indian context, through land use and land cover changes, is required.

Recent studies have shown that remote sensing imageries are used to examine urban sprawl. [8]-[11]. These methods help to track spatial and temporal shifts in urban land use. With remote sensing and GIS data, statistical techniques are used to measure and estimate urban sprawl [12]. Entropy is a robust statistical method for assessing sprawl size.

This research aims to examine the dynamics of urban sprawl in Varanasi city. The study tries to analyze the extent of sprawl with change in the population and land use. The changes in urban land-use have been monitored over the last two decades via satellite imagery. The extent of sprawl is also statistically computed using Shannon's entropy.

\section{METHODOLOGY}

With land-use transition and sprawl trends, the nature of urban sprawl could be understood. GIS-based layer such as city boundary map is created from the census of India handbook 2011 [13]. A buffer region of 9 km taken from city municipal boundary which acts as a limit of the study area. The buffer is created by ArcGIS 10.1 for detailed field investigation. The Landsat satellite imageries are used to study urban sprawl dynamics. Landsat 5 TM for 1996 and 2017 with 142 path and 42 rows, as well as 142 path and 43 rows were downloaded from United State Geological Survey (USGS) earth explorer [14]. 
Maximum likelihood classification is applied to Landsat images. The study area is divided into six land-use categories; built-up area, vegetation, agriculture, waterbody, sand, and other land use. ESRI ArcGIS 10.1 with the Spatial Analyst extension is used in this study. In order to handle supervised maximum likelihood classification, fifty training samples of each category of land use were taken. The built-up area category represents buildings, residential area, commercial area, roads, highways, parking lots. The other land-use area consists of barren land, open spaces, fallow land. The vegetational area represents vegetational patches. The flow chart of the land-use and urban sprawl detection methodology is shown in Fig. 1.

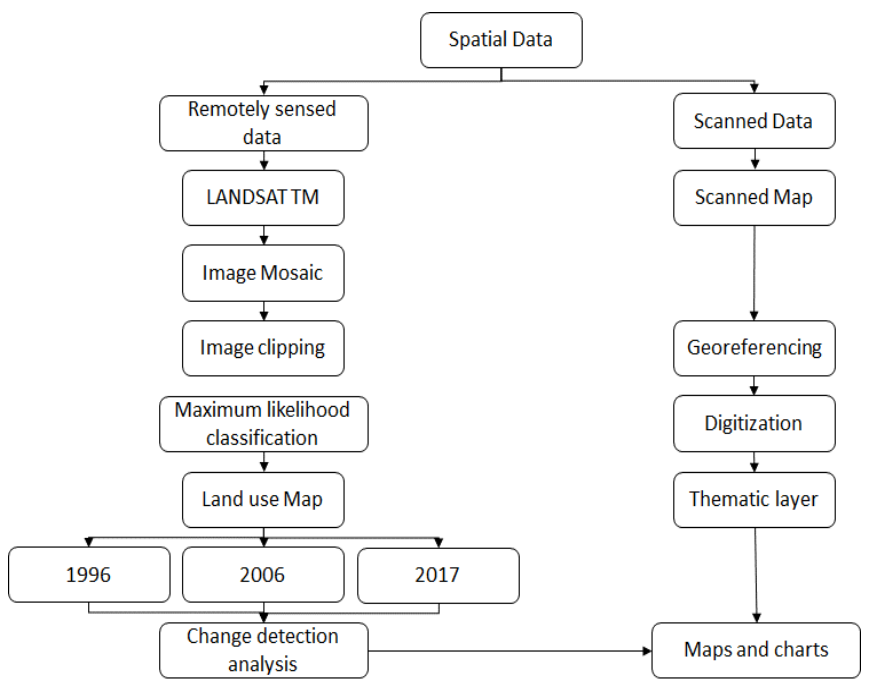

Fig. 1.Flowchart of methodology

\section{MEASUREMENT OF THE URBAN SPRAWL}

Entropy is one of the most commonly used methods to assess the degree of urban sprawl by remote sensing and GIS [11]. Shannon's entropy [15] is used in this analysis to calculate the extent of urban sprawl. It is calculated as,

$$
H_{n}=-\sum_{i=1}^{n} P_{i} \log _{e} P_{i}
$$

where, $P_{i}$ is the proportion of land-use class in the $i^{\text {th }}$ zone and $n$ represents the total number of zones. The entropy has a minimum value of 0 and a maximum value of $\log _{e} n$. A very compact distribution of built-up area is indicated by values closer to zero, whereas, values closer to $\log _{e} n$ signify dispersed distribution.

\section{STUDY AREA}

Varanasi city is considered for the study area. It is amongst the oldest living cities in the world. It is situated in Uttar Pradesh's eastern region. According to the census of India (2011) [13], the district was populated by 36,76,841 peoples of which 17,54,984 were females, and 19,21,857 were males. The total percentage share of the urban population in the district is $43.4 \%$, against the state average of $22.3 \%$. The study area is located between the parallels of $25^{\circ} 15^{\prime}-25^{\circ} 34^{\prime}$ north latitude and $82^{\circ} 50^{\prime}-83^{\circ} 15^{\prime}$ east longitude (Fig. 2). The city encompasses a total area of $1,535.00 \mathrm{sq}$. km.

\section{RESULT AND DISCUSSION}

\section{A. Population Growth}

Varanasi is the $18^{\text {th }}$ most populous district in the state. It stands second, in the state, for population density with 2395 persons per sq. km, and stand seventh in terms of the urban population. The district population increased by $17.15 \%$ to 36.77 lakhs in 2011 from 31.39 lakhs in 2001, according to census of India (2011). Fig. 3 shows population and decadal population growth in Varanasi from 1971 till 2011 [16]. Fig. 4 presents the population growth rate of Varanasi from 1971 till 2011. The district consists of 39 urban centers. Of the 39 urban centers, 3 urban centers make up $80 \%$ of the total urban district population. The city had a population of 11.98 lakhs, according to Census 2011. The population of Varanasi city accounts for 3.6 percent of the state's urban population and 75 percent of the district's urban population. It is followed by Ramnagar, and Lohta at $3 \%$, and $2 \%$, respectively. These percentages point towards the dominant presence of Varanasi city in the district [17].

\section{B. Urban Sprawl of Varanasi City}

The increasing population, coupled with rapid urbanization, causes continuous change at the center of the city. The city's expansion is a complex problem. Urbanization rate and scale also drive a shift in pattern of land use.

Such changes in urban periphery or urban sprawl are characterized by arbitrary and uncoordinated growth with negative effects on vegetation, agriculture land, and water bodies.

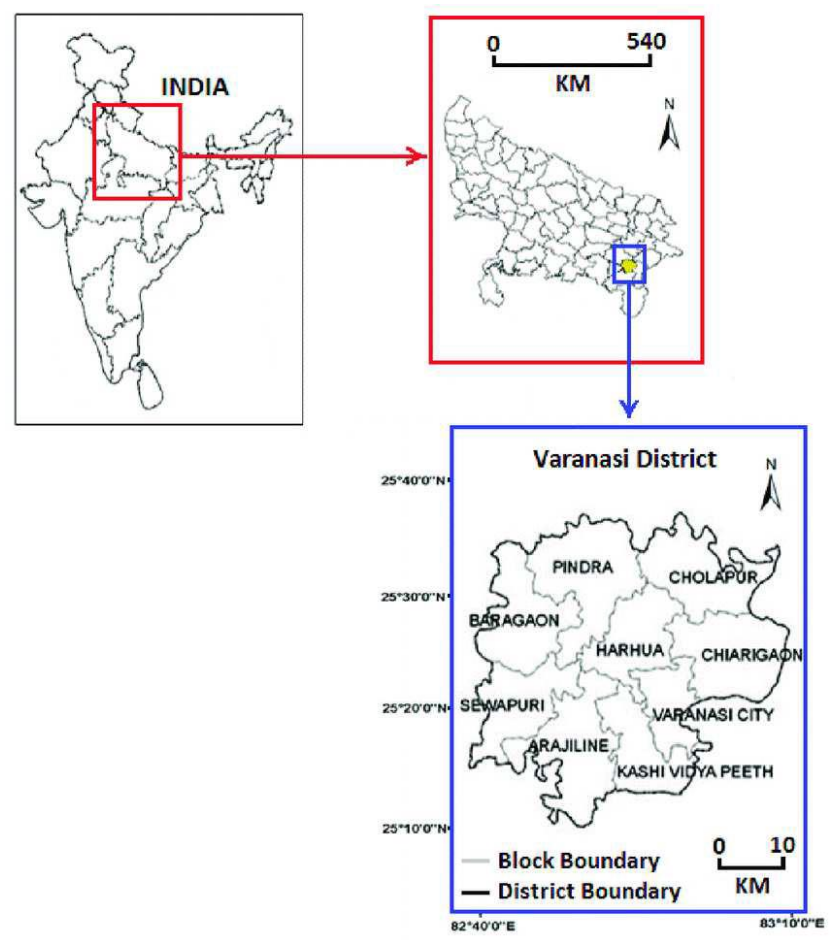

Fig. 2.The study area: Varanasi.

Published By: 


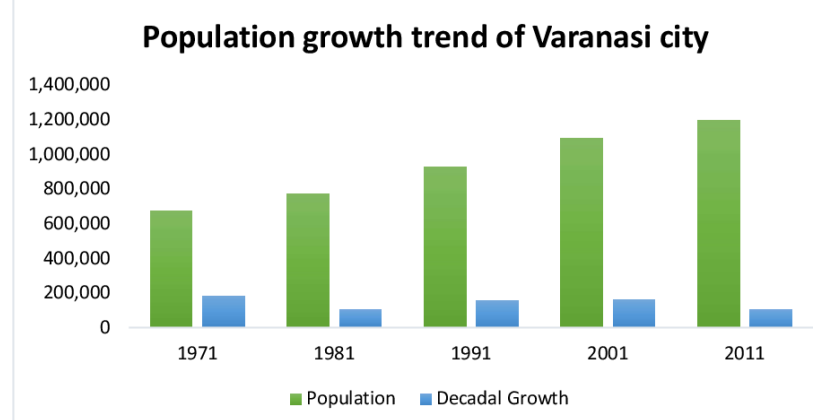

Fig. 3.The population growth trend for Varanasi.

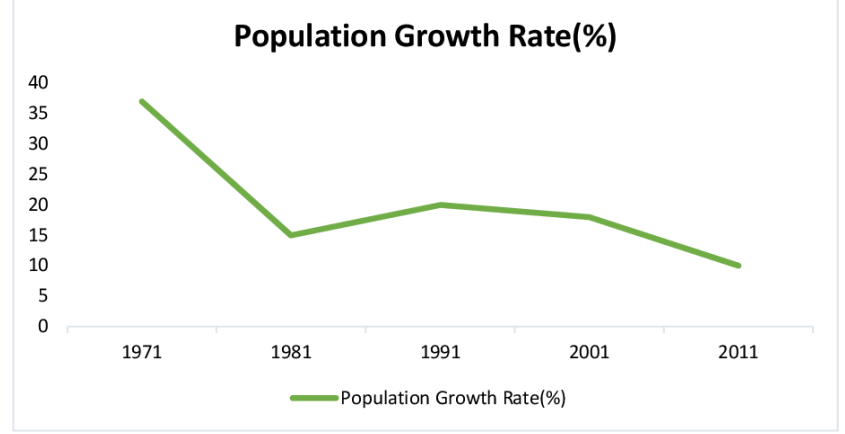

Fig. 4.Population growth rate of Varanasi over last four decades.

The sprawl generally extends in radial, and linear direction along city centers, and highways, respectively [1].

Varanasi city and surrounding urban landscape dynamics for the years 1996 and 2017 have been evaluated using topographic maps, temporal remote sensing, and GIS. GIS-based layer such as city boundary map is created from the census of India handbook 2011. The urban sprawl spatial patterns resulting from the study of $30 \mathrm{~m}$ resolution data from Landsat 5 TM for the year 1996, 2017 are shown in Fogs. 5 and 6. Fig. 7 presents a map showing urban sprawl of 2017, superimposed on urban sprawl of 1996, for Varanasi city.

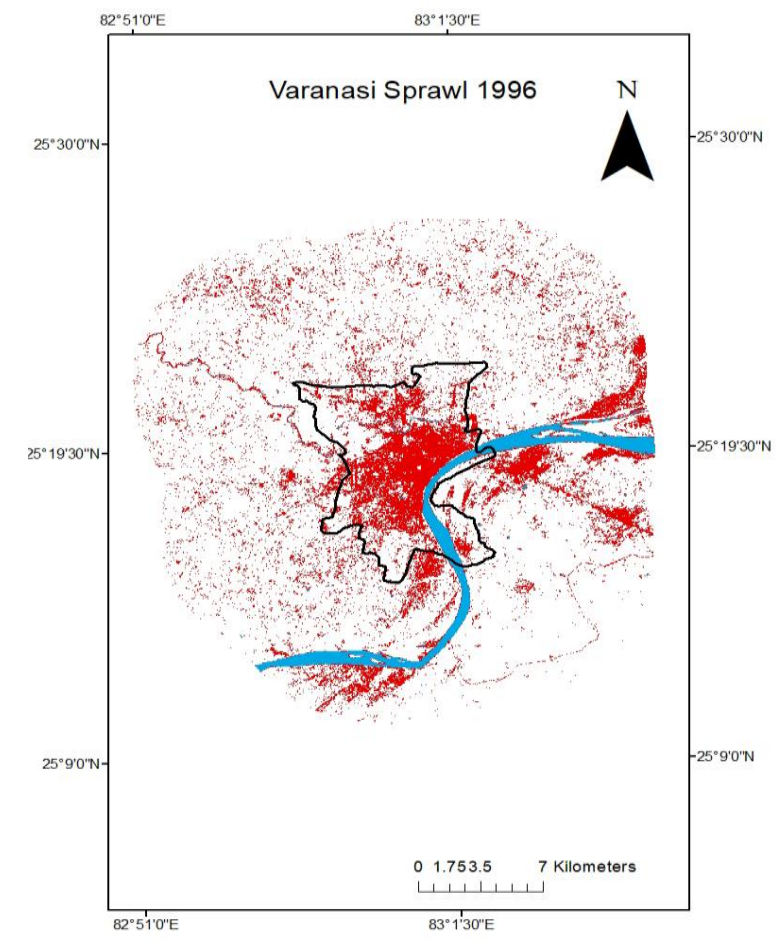

Fig. 5.Urban sprawl of Varanasi city in 1996.

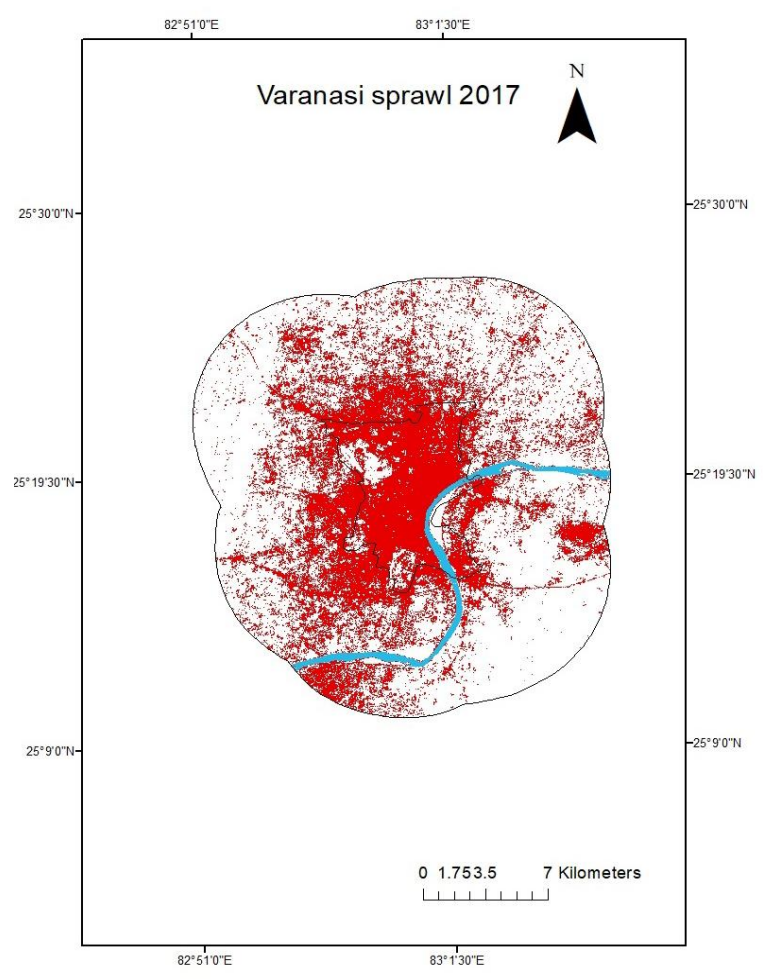

Fig. 6.Urban sprawl of Varanasi city in 2017.

The entropy value is calculated for two periods, i.e., 1996 and 2017.

The entropy value of 1996 is 1.025 , and the entropy value for 2017 is 1.044 (Fig. 8). Shannon's entropy's upper limit is 1.098. The higher entropy value, close to the upper limit, indicates sprawl incidence with a dispersed built-up region distribution.

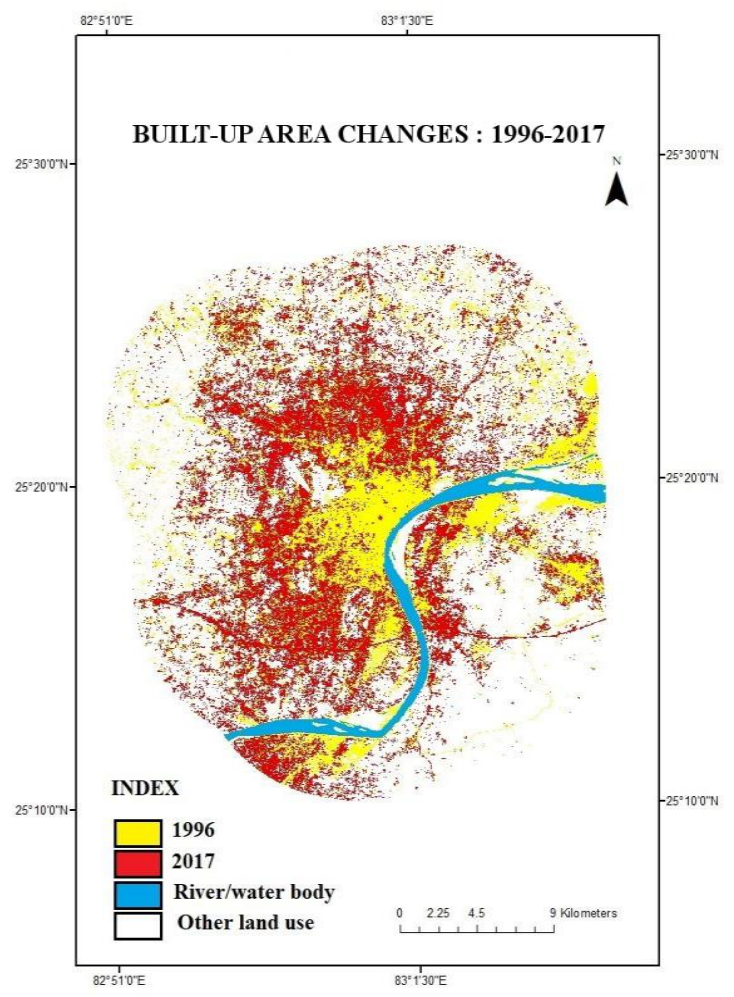

Fig. 7.Built-up area changes from 1996 to 2017.

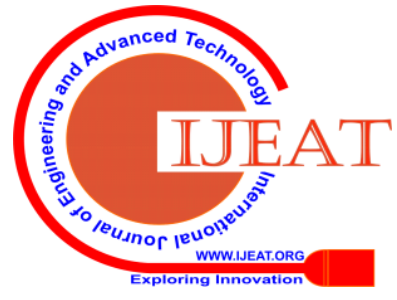




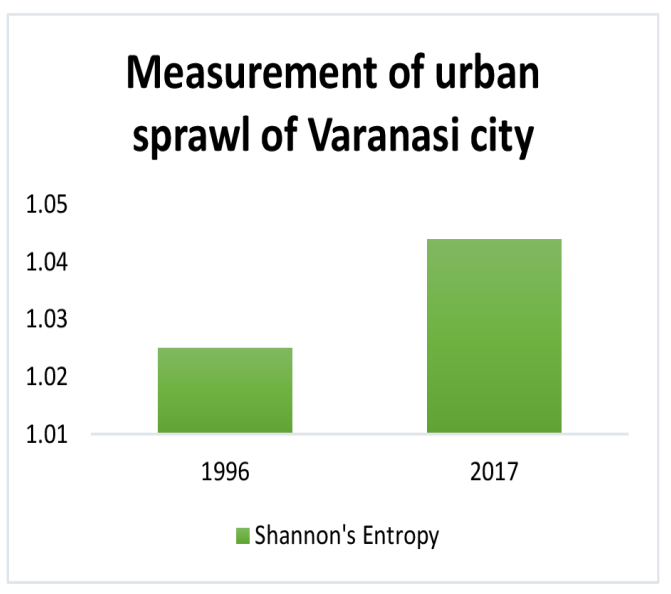

Fig. 8.Measurement of urban sprawl of Varanasi city

\section{Urban Land use of Varanasi City: 1996-2017}

Land use and land cover are two different words that are often used interchangeably. Land use is characterized as human land use with the purpose of obtaining goods and benefits through the use of land resources. Whereas land cover corresponds to the physical traits of the earth's surface, including the composition of vegetation, water, soil, exposed rocks, and agriculture [18].

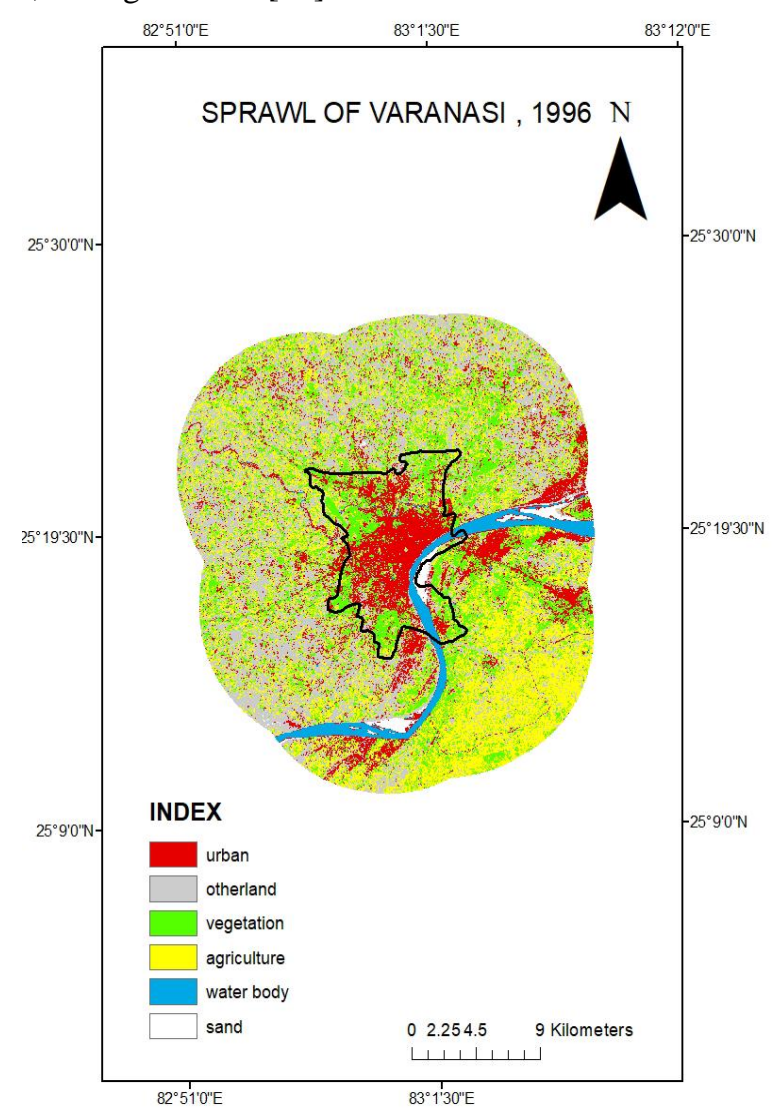

Fig. 9.Land use pattern for Varanasi city in 1996.

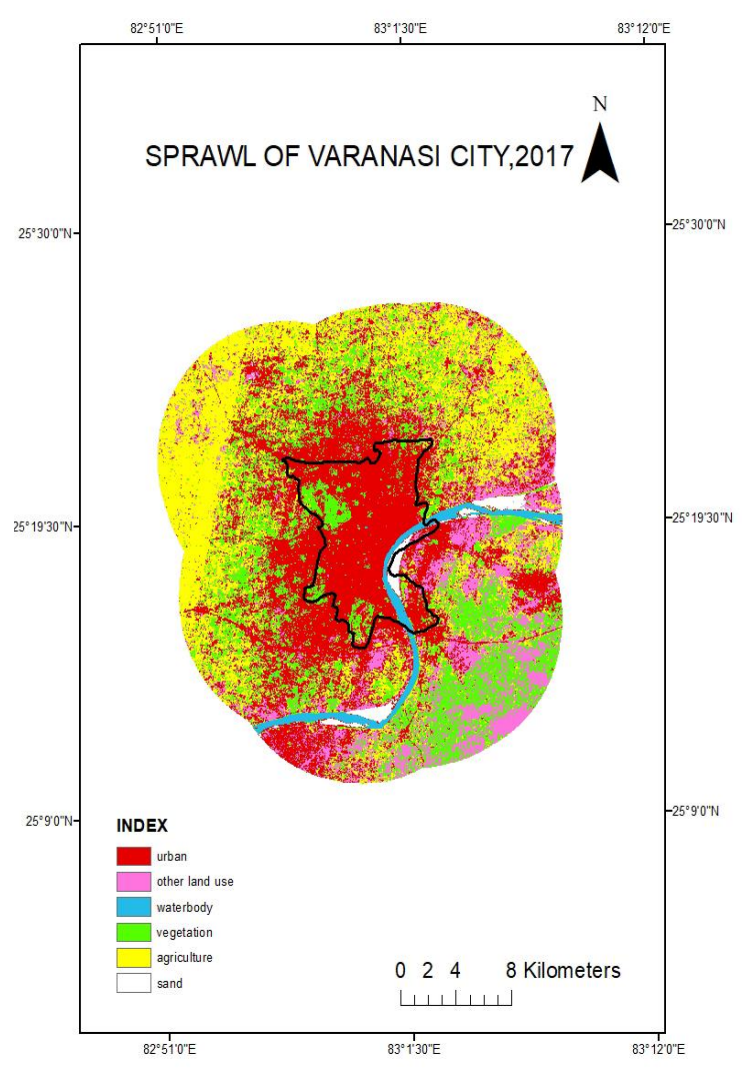

Fig. 10. Land use pattern for Varanasi city in 2017.

The geographical distribution of land use in an urban area is of most crucial attention to the geographer and city planner. While studying the peri-urban area of Varanasi city, the whole area was divided into six categories: built-up area, vegetation, agriculture area, water bodies, sand and other land use.

The other land use category consists of barren land, fallow land, and quarries. Figs. 9 and 10 represent land-use under different classes in Varanasi city for the year 1996, and 2017, respectively. Table 1 tries to capture the dynamics of land use in Varanasi city from 1996 to 2017.

- Built-up: There is a tremendous change in the built-up area from 1996 to 2017. The built-up area of Varanasi city was 110.74 sq. $\mathrm{km}$ in 1996 , and it increases up to $256.14 \mathrm{sq}$. $\mathrm{km}$ in 2017 at $131.28 \%$. The total built-up area saw an increase of 145.4 sq. km (Fig. 11). According to Fig. 9, the built-up area was observed in the central part of the Varanasi city, denoted by urban in the index. According to Fig. 10, the built-up area has increased in the north, west, and northeast. The development of industries, road network growth, and urbanization and residential colonies are the significant factors of this random and haphazard development of the built-up area. The built-up area also developed along the river Ganga and Varuna. The national highway 7, and G.T. road also show dense built-up area due to strong connectivity between Varanasi city and Mughalsarai railway station. This area is covered by residential, industrial and educational places, and road network.

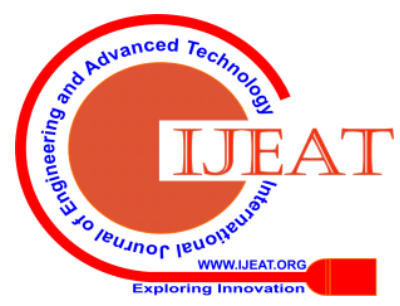




\section{Growth of built-up area of Varanasi city}

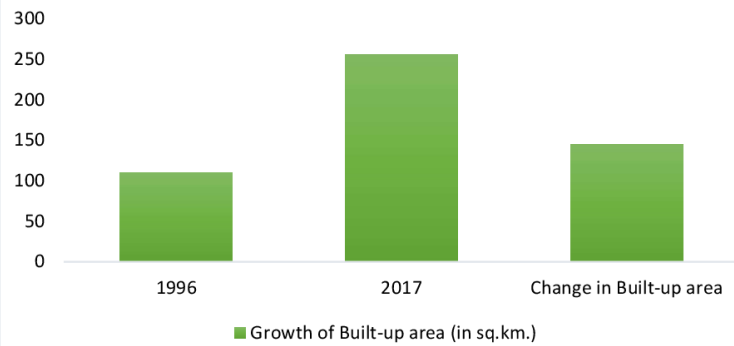

Fig. 11. Expansion of the built-up area (in sq. $\mathbf{k m}$ ). Compared to 1996, the built-up area covered nearly the entire region in 2017, where built-up cover was mostly around Banaras Hindu University, Cantonment, and Diesel Locomotive Works region. Fig. 10 depicts that the southwest part of the Mirzapur is having a dense patch of built-up area. The southern portion of the study area is a host of national highway 2, Marwahdih road and national highway 7. These roads are the main reason for built-up area development in the peri-urban area. The west and southwest region of the city show a significant increase in the built-up area. The reasons are the presence of Lohta weaving industry, Chandpur industrial area, Diesel Locomotives Works and Banaras Hindu University. The tremendous growth of the built-up area during 1996-2017 reciprocates the pace of development in the peri-urban area of Varanasi city.

- Vegetation: According to Table 1, the land under vegetation was 153.011 sq. $\mathrm{km}$ in 1996, whereas, it was 152.0316 sq. $\mathrm{km}$ in 2017. Thus, as compared to 1996 , vegetation in 2017 has negligible decline by $-0.9794 \mathrm{sq} . \mathrm{km}$ $(-0.64 \%)$. The northwest portion of the study area shows a reduction in the vegetational area in 2017 (Fig. 10). However, there is an increase in vegetation in the southeast area of the city. The vegetational area in the northwest area was taken up by built-up and agricultural region. Also, in 1996 patches of vegetation are present adjacent to river Ganga and Varuna
(Fig. 9), but as seen in Fig. 10, these patches of vegetation have diminished with the time. However, the net vegetation area remains unchanged during 1996-2017, as the garden around the agricultural, residential, and industrial area are included in vegetation.

- Agriculture: Agricultural land use has slightly increased by $6.8148 \mathrm{sq}$. km. It jumped up from 223.263 sq. km in 1996 to 230.0778 sq. $\mathrm{km}$ in 2017. Fig. 10 shows that in 2017, parts of north, northwest, northeast, along with the southern region of the study area has denser agricultural land in comparison to 1996 (Fig. 9). Paddy cultivation has led to an increase in agricultural land use in these areas. However, in 2017, the southeast part of the study area shows a reduction in the agricultural area in comparison to 1996. In 1996, the northern part of river Varuna and eastern part of river Ganga had dense agricultural land. However, in 2017, there is barely any agricultural land in the upper region of the Varuna river. The agricultural land in the eastern region of the Ganga river has also reduced. Built-up area has taken the place of agriculture land in these regions.

- Waterbody: As presented in Table 1, the area under water bodies was 22.86 sq. $\mathrm{km}$ in 1996. The area under water bodies is 17.65 sq. $\mathrm{km}$ in 2017. The area covered by water bodies has drastically reduced by $22.78 \%$. The increasing population and built-up area with reducing resources of water pose a severe challenge to sustainable development. Ganga river and Varuna river shrinks due to pollution, siltation, and over-extraction of river water.

- Other Land Use: Table 1 shows that land use under other categories was 247.366 sq. km, and $101.097 \mathrm{sq}$. km, in 1996 2017, respectively. The total reduction in the area is 146.269 sq. $\mathrm{km}$. The depletion of other land use in 2017 was mainly observed in the north and northwest part (Fig. 10).

Table- I: Peri-urban area of Varanasi city: Land use detection from 1997-2017

\begin{tabular}{|c|c|c|c|c|c|c|}
\hline Land use type & $\begin{array}{c}\text { Area 1996 (in sq. } \\
\mathrm{km})\end{array}$ & $\begin{array}{c}\text { Area 1996 } \\
(\%)\end{array}$ & $\begin{array}{c}\text { Area } 2017 \text { (in sq. } \\
\mathrm{km})\end{array}$ & $\begin{array}{c}\text { Area 2017 } \\
(\%)\end{array}$ & $\begin{array}{c}\text { Absolute change (in sq. } \\
\mathrm{km})\end{array}$ & $\begin{array}{c}\text { \% Growth rate } \\
(1996-2017)\end{array}$ \\
\hline Built-up & 110.745 & 14.62 & 256.1409 & 33.83 & 145.39 & 131.28 \\
\hline $\begin{array}{c}\text { Other land } \\
\text { use }\end{array}$ & 247.366 & 32.67 & 101.097 & 13.35 & -146.26 & -59.13 \\
\hline Vegetation & 153.011 & 20.21 & 152.0316 & 20.08 & -0.9794 & -0.64 \\
\hline Agriculture & 223.263 & 29.49 & 230.0778 & 30.39 & 6.8148 & 3.05 \\
\hline Waterbody & 22.8609 & 3.01 & 17.6527 & 2.35 & -5.2082 & -22.78 \\
\hline Total & 757 & 100 & 757 & 100 & & \\
\hline
\end{tabular}

The spatio-temporal maps highlight that other land use was converted into the built-up and agricultural region. Only southeast region of the study area comes under wasteland. Some patches of other land use are observed near the Ganga river. Fig. 12 shows the area under different categories in 1996 and 2017 with growth rate.

\section{Land use under different categories: 1996 - 2017}

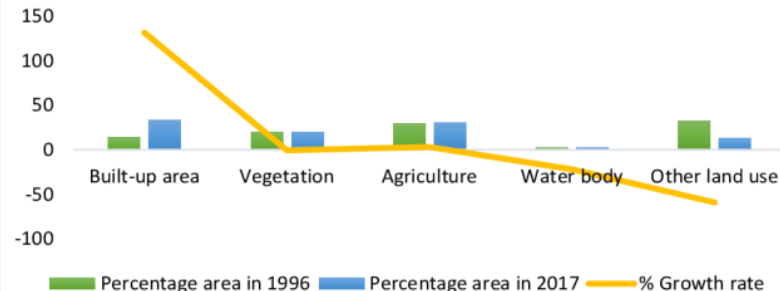

Fig. 12. Land use area under different categories and their growth rate in Varanasi city change since 1996.

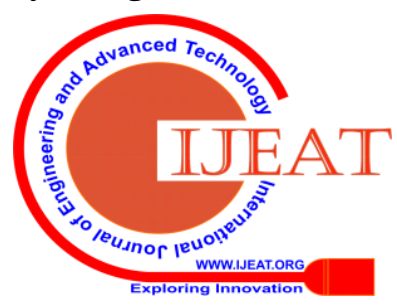




\section{Urban Sprawl Assessment and Its Effect on Land Use Transformation in Varanasi City using Remote Sensing and GIS}

\section{CONCLUSION}

This paper analyzes the dynamics of Varanasi city's urban sprawl by means of remote sensing imaging and GIS. The district's population increased from 31.39 lakhs in 2001 to 36.77 lakhs in 2011, resulting in land use changes. Maximum impact is observed in the built-up area. It encompassed 110.74 sq. $\mathrm{km}$ in 1996, but measures 256.14 sq. $\mathrm{km}$ in 2017 , with a growth rate of $131.28 \%$. The urban area shows dispersed growth in all the directions. The main reasons for this random and haphazard growth are the establishment of industries, road network expansion, and an increase in residential colonies. There is not much change in the area of agricultural and vegetational land. However, the locations of these lands have changed across the city. Water sources and land under other categories are drastically reduced as they are transformed into the built-up area and agricultural region in the outskirts of Varanasi city. Ganga river and Varuna river shrinks due to pollution, siltation, and over-extraction of river water. Calculated Shannon's entropy for built-up area reveals that the growth is significantly decentralized as the value of entropy for 2017 is high at 1.04. This shows that Varanasi city's urban growth is quite high and requires proper management in order to attain sustainable development. In analyzing the dynamics of urban and peri-urban landscapes, the study also demonstrates the potential of statistical analysis with satellite imaging.

\section{REFERENCES}

1. I. R. Hegazy and M. R. Kaloop, "Monitoring urban growth and land use change detection with GIS and remote sensing techniques in Daqahlia governorate Egypt," Int. J. Sustain. Built Environ., vol. 4, no. 1, pp. 117-124, Jun. 2015.

2. A. M. Dewan and Y. Yamaguchi, "Land use and land cover change in Greater Dhaka, Bangladesh: Using remote sensing to promote sustainable urbanization," Appl. Geogr., 2009.

3. Z. Hassan et al., "Dynamics of land use and land cover change (LULCC) using geospatial techniques: a case study of Islamabad Pakistan," Springerplus, vol. 5, no. 1, p. 812, Dec. 2016.

4. J. P. Horo and M. Punia, "Urban dynamics assessment of Ghaziabad as a suburb of National Capital Region, India," GeoJournal, vol. 84, no. 3, pp. 623-639, Jun. 2019

5. J. Xiao et al., "Evaluating urban expansion and land use change in Shijiazhuang, China, by using GIS and remote sensing," Landsc. Urban Plan., vol. 75, no. 1-2, pp. 69-80, Feb. 2006.

6. B. Bhatta, S. Saraswati, and D. Bandyopadhyay, "Urban sprawl measurement from remote sensing data," Appl. Geogr., vol. 30, no. 4 pp. 731-740, Dec. 2010.

7. United Nations Department of Economic and Social Affairs, "World Urbanization Prospects: The 2018 Revision," 2018.

8. C. Canedoli, F. Crocco, R. Comolli, and E. Padoa-Schioppa, "Landscape fragmentation and urban sprawl in the urban region of Milan," Landsc. Res., vol. 43, no. 5, pp. 632-651, 2018.

9. G. Kristy, "The impact of urban sprawl on cultural heritage in Herat, Afghanistan: A GIS analysis,” Digit. Appl. Archaeol. Cult. Herit., 2018.

10. M. Punia and L. Singh, "Entropy Approach for Assessment of Urban Growth: A Case Study of Jaipur, INDIA," J. Indian Soc. Remote Sens., 2012.

11. H. S. Sudhira, T. V Ramachandra, and K. S. Jagadish, "Urban sprawl: metrics, dynamics and modelling using GIS," Int. J. Appl. Earth Obs. Geoinf., vol. 5, no. 1, pp. 29-39, Feb. 2004.

12. D. Ozturk, “Assessment of urban sprawl using Shannon's entropy and fractal analysis: a case study of Atakum, Ilkadim and Canik (Samsun, Turkey),” J. Environ. Eng. Landsc. Manag., vol. 25, no. 3, pp. 264-276, 2017.

13. District Census Handbook: Varanasi, vol. Series-10. 2011. [Online]. Available: (http://censusindia.gov.in/2011census/dchb/DCHB_A/09/0966_PART_ A_DCHB_VARANASI.pdf)

14. USGS, "EarthExplorer | USGS," United States Geological Survey. 2019. [Online]. Available: (https://earthexplorer.usgs.gov/)
15. A. G. O. Yeh and X. Li, "Measurement and monitoring of urban sprawl in a rapidly growing region using entropy," Photogramm. Eng. Remote Sensing, 2001.

16. Directorate of Census Operations, "District Census Handbook Varanasi: Village \& Town Directory Primary Census Abstract," 2001.

17. Ministry of Urban Development, Government of India and The World Bank, "City Development Plan for Varanasi, 2041,” 2015.

18. J. S. Rawat and M. Kumar, "Monitoring land use/cover change using remote sensing and GIS techniques: A case study of Hawalbagh block, district Almora, Uttarakhand, India,” Egypt. J. Remote Sens. Sp. Sci., vol. 18, no. 1, pp. 77-84, Jun. 2015.

\section{AUTHORS PROFILE}

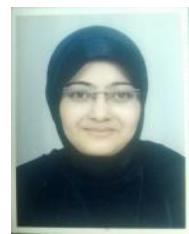

Uzma Ashraf is a research scholar in Department of Geography, Aligarh Muslim University Aligarh. She completed her B.A. in 2009, and M.A in 2013 from Banaras Hindu University where she specialized in geography. She joined as $\mathrm{PhD}$ candidate in Aligarh Muslim University in 2015. Her interest is primarily in Remote Sensing and GIS, Regional Planning, Smart City Planning, Environmental Impact Assessment, Urban Geography, Settlement Geography and Quantitative Geography. She is currently working on application of remote sensing and GIS for analyzing land use transformation. Moreover, She has attended many National \& International Conferences and Seminars and presented four research papers.

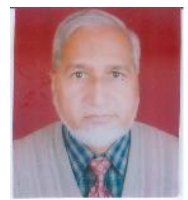

Abdul Munir is a distinguished teacher in Geography. He taught in Shibli National P.G. College, Azamgarh. After obtaining Ph.D. degree in 1987, he started teaching in A. M. U., Aligarh. He retired as professor in Department of Geography, Aligarh Muslim University in 2018. Prof. Munir has a wide-ranging interest in many branches of Geography but specializes in Agricultural Geography, Urban Geography, Settlement Geography and Quantitative Geography. Prof. Munir has supervised 20 M. Phil and Ph. D. students. He has credited numerous research papers in the field of Applied Geography in the journals of National and International repute. His outstanding papers published in Asian Profile, Canada are related to urban environment of Aligarh city, forest ecology of Uttarakhand and population and food grains production in Uttar Pradesh. Besides, he has authored and edited eight volumes on agriculture, resource development, environment and poverty. He has attended 30 national and international conferences in India and abroad.

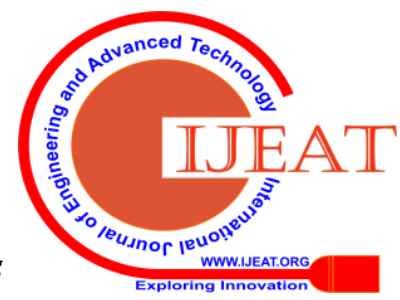

